\title{
Antibacterial Effect of Coconut Oil (Cocus nucifera) on Streptococcus mutans ATCC 25175: An In vitro Study
}

\author{
Efecto Antibacteriano de Aceite de Coco (Cocus nucifera) Sobre \\ Streptococcus mutans ATCC 25175: Un Estudio in vitro
}

\author{
Grecia Vásquez Vereau¹ \& Gustavo Guardia Méndez ${ }^{1,2}$
}

VÁSQUEZ, V. G. \& GUARDIA, M. G. Antibacterial effect of coconut oil (Cocus nucifera) on Streptococcus mutans ATCC 25175: an in vitro study. Int. J. Odontostomat., 15(4):922-927, 2021.

ABSTRACT: The present in vitro study determined the antibacterial effect of Coconut (Cocus nucifera) oil on Streptococcus mutans ATCC 25175. Cross-sectional and experimental study. Streptococcus mutans strain ATCC 25175 was seeded on MüellerHinton Blood Agar. The effect was determined by inhibition halo and the minimum inhibitory concentration, using procaine penicillin $\mathrm{G}$ as a positive control and standard suspension of Streptococcus mutans as a negative control. Twelve replicates per Coconut oil concentration ( $25 \%, 50 \%$ and $75 \%$ ) were performed. Coconut oil concentration at $25 \%$ generated an inhibitory mean of $17 \mathrm{~mm}$ and $2.23 \times 10^{2} \mathrm{CFU}$, at $50 \%$ a mean of $21.75 \mathrm{~mm}$ and $0.17 \times 10^{2} \mathrm{CFU}$, at $75 \%$ a mean of $22 \mathrm{~mm}$ and $0 \mathrm{CFU}$, procaine penicillin $\mathrm{G}$ a mean of $14.25 \mathrm{~mm}$ and $0 \mathrm{CFU}$, the negative control gave a mean of $2.8 \times 10^{5} \mathrm{CFU}$. The Kruskal-Wallis non-parametric test detected a highly significant statistical difference of the three concentrations of Coconut oil $(p<0.01)$. The Mann-Whitney test with Bonferroni adjustment determined that the $50 \%$ and $75 \%$ concentration had similar inhibitory action and that both the $75 \%$ concentration and procaine penicillin G gave a mean of 0 CFU. All concentrations of Coconut oil showed inhibitory action on Streptococcus mutans ATCC 25175. 75 \% concentration showed the highest inhibitory mean and was the minimum inhibitory concentration that completely eliminated CFU.

KEY WORDS: coconut oil, Streptococcus mutans, antibacterial agents.

\section{INTRODUCTION}

Currently, there is a growing interest based on the development of techniques and the search for products for the treatment and prevention of dental caries, which is highly prevalent worldwide and in which Streptococcus mutans is the cause due to its ability to synthesize extracellular polymers, aciduricity and acidogenicity (Lemos et al., 2019; Romero-González., 2020). Although the use of drugs helps to treat various oral conditions, some of these have adverse effects (Tartaglia et al., 2019). For this reason, there is a constant search for and use of natural resources to help prevent disease and maintain oral health, especially in developing countries such as India, where people use natural oils as oral rinses through a technique called "Oil Pulling" (Naseem et al., 2017; Rupani et al., 2018). One of the most commonly used oils in this technique is coconut (Cocus nucifera) oil (Woolley et al., 2020), which contains predominantly medium-chain saturated fatty acids (Chatterjee et al., 2020) that are metabolized more easily and quickly than long-chain fatty acids because they are smaller, more soluble and more stable against oxidation (Restrepo et al., 2020). Coconut oil is $50 \%$ lauric acid (Ghani et al., 2018), to which antibacterial, antiviral and antiprotozoal properties are attributed, especially to its monoglyceride, monolaurin (Joshi et al., 2020; Silva et al., 2018). In Peru, little is known about the antibacterial action of Coconut oil on Streptococcus mutans and, since this is related to the high prevalence of dental caries, it is necessary to include easily extractable, low-risk natural substances in daily oral hygiene products that help to slow the development and progression of dental caries. The aim of the present study was to determine the in vitro antibacterial effect of Coconut (Cocus nucifera) oil on the growth of Streptococcus mutans.

\footnotetext{
${ }^{1}$ Dental surgeon, Peru.

2 Senior lecturer National University of Trujillo, Peru.
} 


\section{MATERIAL AND METHOD}

Experimental cross-sectional "in vitro" study carried out at the Pharmacognosy and Microbiology Laboratory of the National University of Trujillo. The handling and disposal of the Streptococcus mutans ATCC 25175 strain was carried out according to the Biosafety manual of the Microbiology and Medicine Laboratories. Authorisation was obtained from the Permanent Research Committee of the Faculty of Stomatology of the National University of Trujillo and the principles of the Declaration of Helsinki were followed.

The study population consisted of a set of Petri dishes containing each of the different concentrations of Coconut oil with adequate seeding of Streptococcus mutans $(3 \times 108 \mathrm{CFU} / \mathrm{ml})$. Plates with adequate Streptococcus mutans seeding a priori to the oil challenge that showed inhibition or non-inhibition of bacterial growth were included. Petri dishes that showed contamination (other bacteria or fungi) after the incubation process were excluded.

Sample size. The calculation for the number of tests was determined by the following formula (1):

$$
\mathrm{n}=\frac{2 *\left(\mathrm{z}_{\alpha / 2}+\mathrm{Z}_{\beta}\right)^{2} * \mathrm{DE}^{2}}{\mathrm{~d}^{2}}
$$

Assuming the requirements of $90 \%$ confidence $(=0.10 Z=1.64)$ a test power of $80 \%(=0.20 ; Z=0.84) a$ ratio of $\mathrm{SD} / \mathrm{d}=1.00$ is obtained: (Formula 2 )

$$
n=2(1.64+0.84)^{2} /(1.00)^{2}=12
$$

Therefore, 12 replicates per concentration were performed.

Collection and preparation of the strain. Streptococcus mutans strain ATCC 25175 was obtained from the cepario of the Microbiology Laboratory of the Faculty of Medicine of the National University of Trujillo, was grown in thioglycollate broth and incubated for 48 hours at $37^{\circ} \mathrm{C}$. Strain growth was confirmed when a strong turbidity was observed in the test tubes. Petri dishes were prepared on MüellerHinton Agar medium spiked with $5 \%$ rabbit blood.

Collection and taxonomic identification of Cocus nucifera. The fruit Cocus nucifera was obtained from the district of Tarapoto, province of San Martin, San
Martin region (Peru). A complete specimen of the fruit was taken to the Herbario Truxillense (HUT) of the National University of Trujillo, for identification and subsequent taxonomic verification.

Preparation of Coconut oil. The oil was extracted by cold pressing. The rind was cut with the respective fruit hairs and then washed with distilled water and disinfected with $0.5 \%$ sodium hypochlorite. Subsequently, the "eyes" or germination pores of the fruit were punctured to remove water and the coconuts were opened. The pulp was removed and cut into small pieces. The pulp was then grated and mixed with distilled water in a blender to form a paste and filtered through sterile gauze, separating the mass from the coconut milk. The coconut milk was then placed in a plastic bottle and left in a dark place for 48 hours. After this time, the bottle was placed in the refrigerator fridge for 24 hours, where the coconut oil and pulp formed a solid layer on top through a decanting process. With the help of scissors, the bottle was opened and the solid mixture of oil and pulp was removed. It was then placed in a water bath until it became a liquid. It was then strained and the oil was separated from the pulp. The strained oil was placed in an amber glass bottle.

Dilution of Coconut oil. Once the Coconutoil was obtained, dilutions were made using Polysorbate 80 as solvent to obtain concentrations of $25 \%, 50 \%$ and $75 \%$.

Inhibition halo (susceptibility test). To determine the inhibition halo, the Kirby and Bauer disc diffusion technique was used, for which sterile filter paper discs were immersed in each concentration of Coconut oil (25\%,50\% and $75 \%$ ) for 1 hour. The discs were placed over the Streptococcus mutans cultures in the petri dishes and incubated at $37^{\circ} \mathrm{C}$ in micro anaerobiosis. Discs embedded in procaine penicillin $G$ were used as a positive control. After 24 hours, inhibition halos were measured with a Vernier caliper. The diameters of these zones were measured in $\mathrm{mm}$, according to the Duraffourd scale, which is used to qualitatively determine the inhibitory effect in vitro and has the following indicators:

- Null (-): Diameter less than $8 \mathrm{~mm}$.

- Sensitive (+): Diameter between 8 to $14 \mathrm{~mm}$.

- Very sensitive (++): Diameter between 14 and $20 \mathrm{~mm}$. - Highly sensitive (+++): Diameter greater than $20 \mathrm{~mm}$.

Minimum inhibitory concentration. To determine the minimum inhibitory concentration, $0.8 \mathrm{ml}$ of each concentration of Coconut oil was placed in test tubes 
and $0.2 \mathrm{ml}$ of Streptococcus mutans culture was added to each tube. Procaine penicillin $G$ was used as a positive control and Streptococcus mutans standard suspension was used as a negative control. The tubes were placed in the Gas-Pack Jar at $37^{\circ} \mathrm{C}$ for 24 hours. $0.1 \mathrm{ml}$ of each suspension was dispersed in petri dishes with Müeller-Hinton Blood Agar. After 24 hours, CFU counting was performed using the viable bead method by visual inspection. It was considered as ineffective when colony formation was recorded on visual inspection, and effective when colony formation of Streptococcus mutans ATCC 25175 growth was not observed.

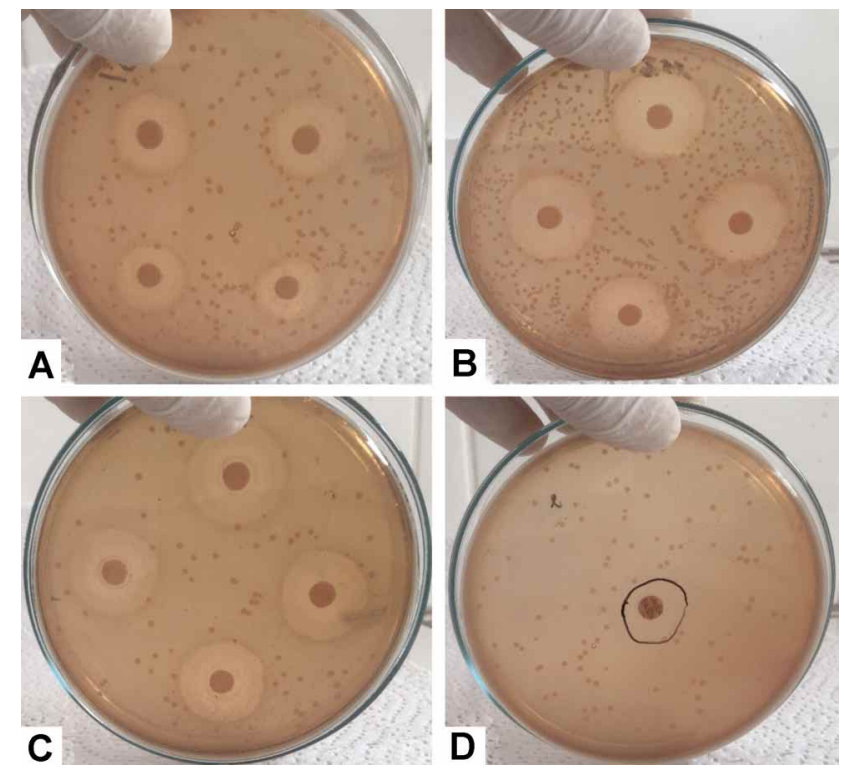

Fig. 1. A. Concentration inhibition halos at $25 \%$ concentration. B. Concentration inhibition halos at $50 \%$ concentration. C. Concentration inhibition halos at $75 \%$. D. Inhibition halo of the control group (procaine penicillin $\mathrm{G}$ ).
Statistical analysis. For the statistical analysis, due to the lack of fulfilment of some basic assumptions for the F-test of the analysis of variance to be valid, the non-parametric Kruskal-Wallis test for a one-way completely randomized design was used as an alternative, considering that there is a significant statistical difference if the probability of error is less than $5 \%(p<0.05)$. To complement the analysis and compare pairs of groups, the complementary nonparametric Mann-Whitney test with Bonferroni adjustment was applied with the same significance criterion.

\section{RESULTS}

The Kruskal-Wallis non-parametric test revealed a highly significant difference in the inhibitory action of the three concentrations of Coconut oil $(p<0.01)$.

The $75 \%$ concentration had the highest inhibitory mean at $22 \mathrm{~mm}$, while the positive control (procaine penicillin $\mathrm{G}$ ) had the lowest inhibitory mean at $14.25 \mathrm{~mm}$ (Fig. 1). The Mann-Whitney test with Bonferroni adjustment indicates that the $50 \%$ concentration does not differ in its effect with respect to the $75 \%$ concentration, being considered as "Very sensitive" and "Highly sensitive" for the microorganism according to the Duraffourd scale (Table I). The MannWhitney test with Bonferroni adjustment shows that both the positive control and the $75 \%$ concentration completely inhibit CFU (Table II), the latter being the minimum inhibitory concentration (Fig. 2).

Table I. In vitro antibacterial effect according to the concentration of coconut oil on Streptococcus mutans ATCC 25175 through the diameter of the inhibition halo and according to the Duraffourd scale.

\begin{tabular}{|c|c|c|c|c|}
\hline \multirow{2}{*}{$\begin{array}{l}\text { Halo diameter } \\
\text { indicator }(\mathrm{mm})\end{array}$} & \multicolumn{4}{|c|}{ Study Group: Coconut oil concentration } \\
\hline & $25 \%$ & $50 \%$ & $75 \%$ & Procaine penicillin $\mathrm{G}$ \\
\hline Media & 17.0 & 21.8 & 22.0 & 14.25 \\
\hline Standard Deviation & 1.5 & 0.9 & 0.7 & 0.8 \\
\hline Test K-W + & \multicolumn{2}{|c|}{$\mathrm{X} 2(\mathrm{~K}-\mathrm{W})=40.1$} & \multicolumn{2}{|c|}{$p<0.01$} \\
\hline Mann-Whitney Test & A & $\mathrm{B}$ & $\mathrm{B}$ & $\mathrm{C}$ \\
\hline
\end{tabular}

+ : Non-parametric Kruskal-Wallis test

++ : Non-parametric Mann-Whitney test with Bonferroni adjustment comparing pairs of groups; Two groups with the same letter do not differ statistically.

\begin{tabular}{ccccccccc}
\hline Duraffourd scale & \multicolumn{2}{c}{$25 \%$} & \multicolumn{2}{c}{$50 \%$} & \multicolumn{3}{c}{$75 \%$} & \multicolumn{2}{c}{ Procaine penicillin G } \\
\hline Null & 0 & 0.0 & 0 & 0.0 & 0 & 0.0 & 0 & 0.0 \\
Sensible & 0 & 0.0 & 0 & 0.0 & 0 & 0.0 & 2 & 16.7 \\
Very sensitive & 12 & 100.0 & 1 & 8.3 & 0 & 0.0 & 10 & 83.3 \\
Highly sensitive & 0 & 0.0 & 11 & 91.7 & 12 & 100.0 & 0 & 0.0 \\
TOTAL & 12 & 100.0 & 12 & 100.0 & 12 & 100.0 & 12 & 100.0 \\
\hline
\end{tabular}


Table II. In vitro antibacterial effect according to coconut oil concentration on Streptococcus mutans ATCC 25175 through the number of colony forming (CFU's) and minimum inhibitory concentration (MIC).

\begin{tabular}{|c|c|c|c|c|c|c|c|c|}
\hline \multirow{2}{*}{ CFU number indicator } & \multicolumn{8}{|c|}{ Study group: Cocus nucifera oil concentration } \\
\hline & \multicolumn{2}{|c|}{$25 \%$} & \multicolumn{2}{|c|}{$50 \%$} & \multicolumn{2}{|c|}{$75 \%$} & \multicolumn{2}{|c|}{ Procaine penicillin $\mathrm{G}$} \\
\hline Mean & \multicolumn{2}{|c|}{222.5} & \multicolumn{2}{|c|}{16.9} & \multicolumn{2}{|c|}{0.0} & \multicolumn{2}{|c|}{0.0} \\
\hline Standard Deviation & \multicolumn{2}{|c|}{82.7} & \multicolumn{2}{|c|}{19.1} & \multicolumn{2}{|c|}{0.0} & \multirow{2}{*}{\multicolumn{2}{|c|}{0.0}} \\
\hline K-W Test + & \multicolumn{4}{|c|}{$\mathrm{X}^{2}(\mathrm{~K}-\mathrm{W})=40.3$} & \multicolumn{2}{|c|}{$p<0.01$} & & \\
\hline Mann-Whitney Test ++ & \multicolumn{2}{|c|}{ A } & \multicolumn{2}{|c|}{ B } & \multicolumn{2}{|c|}{$\mathrm{C}$} & \multicolumn{2}{|c|}{$\mathrm{C}$} \\
\hline \multicolumn{9}{|c|}{$\begin{array}{l}+ \text { : Non-parametric Kruskal-Wallis test } \\
++ \text { : Non-parametric Mann-Whitney test with Bonferroni adjustment comparing pairs of groups; Two groups with the same } \\
\text { letter do not differ statistically. }\end{array}$} \\
\hline Minimum inhibitory & \multicolumn{2}{|c|}{$25 \%$} & \multicolumn{2}{|c|}{$50 \%$} & \multicolumn{2}{|c|}{$75 \%$} & \multicolumn{2}{|c|}{ Procaine penicillin $\mathrm{G}$} \\
\hline Yest & 0 & 0.0 & 4 & 33.3 & 12 & 100.0 & 12 & 100.0 \\
\hline No & 12 & 100.0 & 8 & 66.7 & 0 & 0.0 & 0 & 0.0 \\
\hline TOTAL & 12 & 100.0 & 12 & 100.0 & 12 & 100.0 & 12 & 100.0 \\
\hline \multicolumn{9}{|c|}{$+:$ When the number of CFU's $=0$} \\
\hline
\end{tabular}

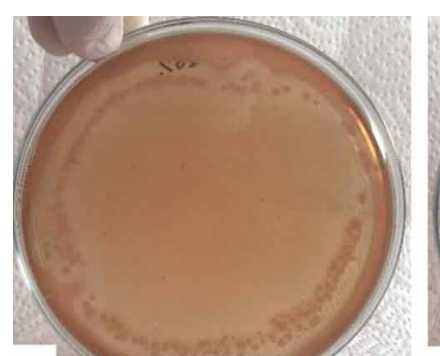

A
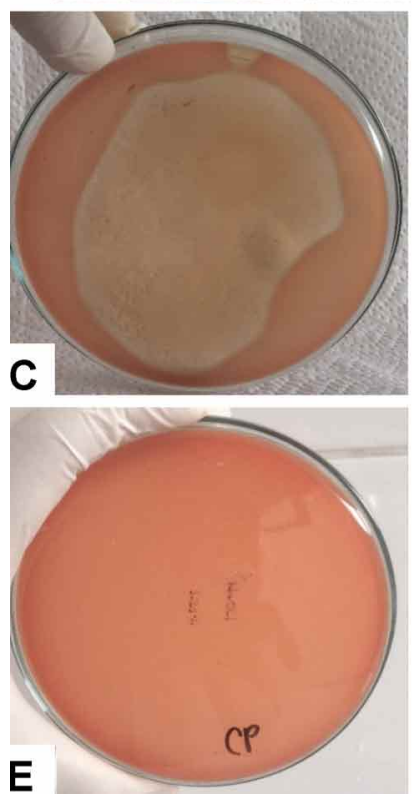

Fig. 2 A. Colony-forming units of the $25 \%$ concentration. B. Colony-forming units of the 50 $\%$ concentration. C. Colonyforming units of the $75 \%$ concentration. D. Colonyforming units of Penicillin procaine $\mathrm{G}$ (Positive control):

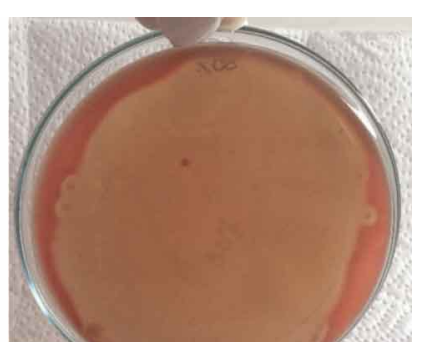

B

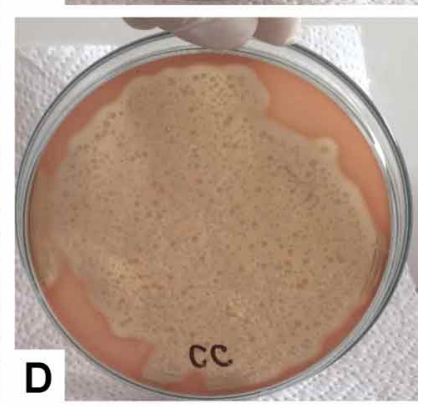

Colony forming units of the $75 \%$ concentration. D. Colony forming units of Penicillin procaine $G$ (Positive control). E. Colony forming units of Streptoccocus mutans sample (Negative control).

\section{DISCUSSION}

It has been reported in the literature that the main component conferring antibacterial properties to coconut oil is monolaurin, a heat-stable monoglyceride produced by the esterification of lauric acid and glycerol. Monolaurin appears to act primarily by destroying a variety of lipid-coated viruses by disrupting their membranes, thus interfering with assembly and maturation (Boateng et al., 2016; Hewlings, 2020). It is also attributed with the ability to permeate cell membranes by rendering the phospholipids of the lipid bilayer more fluid, inhibit membrane enzyme activities and nutrient uptake, and interfere with transduction signalling in bacteria (Khoramnia et al., 2013; Liebermann et al., 2006). Monolaurin also appears to have immunomodulatory effects on proinflammatory cytokine gene expression in fungi (Seleem et al., 2016). Recent studies have reported that oil pulling with coconut oil appears to inhibit plaque similarly to chlorhexidine (as well as generating fewer adverse effects) (Sezgin et al., 2019) and that there are no statistically significant changes in its antibacterial efficacy (Peedikayil et al., 2016). Likewise, some studies have reported that sucrose monolaurate and the glycolipid component present in coconut have anticaries properties, probably due to the condensed glycolysis and oxidation of sucrose in a non-competitive method affecting Streptococcus mutans (Rukmini et al., 2017). Coconut, sesame and olive oils together with chlorhexidine gel have also been reported to significantly reduce Streptococcus mutans and Lactobacillus values (Singla et al., 2014) and Coconut oil has been reported to generate a 
statistically significant decrease in plaque and gingival indices (Peedikayil et al., 2015) however, the controversy lies in the fact that participants were previously exposed to mechanical brushing, attributing the reduction in bacterial numbers to the result of the mechanical removal as well as the strength of the rinsing. Faisal evaluated the inhibitory effect on Streptococcus mutans strains using commercial FIS brand Cocus nucifera oil and revealed an inhibition halo of approximately $15 \mathrm{~mm}$ (Faisal, 2015). Alberca Perea and Colca Solano, also using commercial Coconut oil, found no antibacterial effect on Streptococcus mutans, but their methanolic extract did have an effect with an average inhibition halo of $13+/-1 \mathrm{~mm}$ (Alberca et al., 2018). Torres found that the mean inhibition haloes resulted for chlorhexidine with a mean of $15.47 \mathrm{~mm}$, Cocus nucifera oil at $100 \%$ with a mean of $12.96 \mathrm{~mm}$, at 75 $\%$ with a mean of $12.05 \mathrm{~mm}$, and at $50 \%$ with a mean of $11.17 \mathrm{~mm}$. He determined that the microorganism is significantly more sensitive to 0.12 $\%$ chlorhexidine than to Cocus nucifera oil at all three concentrations (Torres, 2017). In this study, the in vitro antibacterial effect of Cocus nucifera oil on Streptococcus mutans ATCC 25175 was greater than that obtained in previous studies in other countries, which may be attributed to differences in the method of oil extraction, degree of maturity and origin of the fruit and the chemical compounds added to the commercial products. For this reason, studies should be carried out to compare the effect according to these variables. Likewise, inter- and intra-evaluator calibration and validation of the measuring instrument was not carried out, so it is important that this be taken into account in future research. The antibacterial capacity of coconut oil observed in this study may be due to monolaurin, its main component, which is why studies should be carried out to identify its active components and mechanism of action so that it can be included in oral hygiene products, as it is a natural, inexpensive and easily extracted product.

\section{CONCLUSION}

All concentrations of Cocus nucifera (coconut) oil showed in vitro antibacterial effect on Streptococcus mutans ATCC 25175 and the effect varied according to the concentration used, with the $75 \%$ concentration producing the largest inhibition halo at $22 \mathrm{~mm}$ and representing the lowest inhibitory concentration at $0 \mathrm{CFU}$.

\section{ACKNOWLEDGEMENTS}

To Dr. Elva Mejía Delgado of the Microbiology Laboratory of the Faculty of Medicine of the National University of Trujillo - Peru, for processing the samples.

VÁSQUEZ, V. G. \& GUARDIA, M. G. Efecto antibacteriano de aceite de coco (Cocus nucifera) sobre Streptococcus mutans ATCC 25175: Un estudio in vitro. Int. J. Odontostomat., 15(4):922-927, 2021.

RESUMEN: El presente estudio in vitro determinó el efecto antibacteriano del aceite de coco sobre Streptococcus mutans ATCC 25175 . Estudio transversal y experimental. La cepa de Streptococcus mutans ATCC 25175 se sembró en Agar Sangre Müeller-Hinton. El efecto se determinó mediante el halo de inhibición y la concentración inhibitoria, utilizando la penicilina $G$ procaína como control positivo y la suspensión estándar de Streptococcus mutans como control negativo. Se realizaron doce réplicas por cada concentración de aceite de coco $(25 \%, 50 \%$ y $75 \%)$. La concentración de aceite de coco al $25 \%$ generó una media inhibitoria de $17 \mathrm{~mm}$ y $2,23 \times 10^{2}$ UFC, al $50 \%$ una media de 21,75 $\mathrm{mm}$ y $0,17 \times 10^{2}$ UFC, al $75 \%$ una media de $22 \mathrm{~mm}$ y 0 UFC, la penicilina $\mathrm{G}$ procaína una media de $14,25 \mathrm{~mm}$ y 0 UFC, el control negativo dio una media de $2,8 \times 10^{5}$ UFC. La prueba no paramétrica de Kruskal-Wallis detectó una diferencia estadística altamente significativa de las tres concentraciones de aceite de coco $(p<0,01)$. La prueba de Mann-Whitney con ajuste de Bonferroni determinó que las concentraciones del $50 \%$ y del $75 \%$ tenían una acción inhibidora similar y que tanto la concentración del $75 \%$ como la penicilina $\mathrm{G}$ procaína daban una media de 0 UFC. Todas las concentraciones de aceite de coco mostraron una acción inhibitoria sobre Streptococcus mutans ATCC 25175. La concentración del $75 \%$ mostró la media inhibitoria más alta y fue la concentración inhibitoria mínima que eliminó completamente las UFC.

PALABRAS CLAVE: aceite de coco, Streptococcus mutans, agentes antibacterianos.

\section{REFERENCES}

Alberca, S. \& Solano S. Evaluación in vitro de la actividad antibacteriana de los aceites y extractos metanólicos de sésamo, coco y girasol sobre cepas de Streptococcus mutans (ATCC 25175) (Tesis de Pregrado inédita). Universidad Peruana de Ciencias Aplicadas, 2018.

Boateng, L.; Ansong, R.; Owusu, W. B. \& Steiner-Asiedu, M. Coconut oil and palm oil's role in nutrition, health and national development: A review. Ghana Med. J., 50(3):189-96, 2016.

Chatterjee, P.; Fernando, M.; Fernando, B.; Dias.; C. B, Shah, T.; Silva, R.; Williams, S.; Pedrini, S.; Hillebrandt, H.; Goozee, K.; 
Barin, E.; Sohrabi, H. R.; Garg, M.; Cunnane, S. \& Martins, R. N. Potential of coconut oil and medium chain triglycerides in the prevention and treatment of Alzheimer's disease. Mech. Ageing Dev., 186:111209, 2020.

Faisal, R. Efecto del aceite de coco sobre el crecimiento del Estreptococcus mutans in vitro. (Tesis de Pregrado inédita). Universidad de Carabobo, 2015.

Ghani, N. A. A.; Channip, A. A.; Chok Hwee Hwa, P.; Ja'afar, F.; Yasin, H. M. \& Usman A. Physicochemical properties, antioxidant capacities, and metal contents of virgin coconut oil produced by wet and dry processes. Food Sci. Nutr., 6(5):1298-306, 2018.

Hewlings S. Coconuts and health: different chain lengths of saturated fats require Different consideration. J. Cardiovasc. Dev. Dis., 7(4):59, 2020.

Joshi, S.; Kaushik, V.; Gode, V. \& Mhaskar, S. Coconut oil and immunity: what do we really know about it so far? J. Assoc. Physicians India, 68(7):67-72, 2020.

Khoramnia, A.; Ebrahimpour, A.; Ghanbari, R.; Ajdari, Z. \& Lai, OM. Improvement of medium chain fatty acid content and antimicrobial activity of coconut oil via solid-state fermentation using a Malaysian Geotrichum candidum. Biomed Res. Int., 2013:954542, 2013.

Lemos, J. A.; Palmer, S. R.; Zeng, L.; Wen, Z. T.; Kajfasz, J. K.; Freires, I. A.; Abranches, J. \& Brady, L. J. The Biology of Streptococcus mutans. Microbiol Spectr., 7(1):10.1128/ microbiolspec.GPP3-0051-2018, 2019.

Liebermann, S.; Enig, M. \& Preuss, H. A review of monolaurin and lauric acid: natural virucidal and bactericidal agents. Altern. Complement. Ther., 12(6):310-4, 2006.

Naseem, M.; Khiyani, M. F.; Nauman, H.; Zafar, M. S.; Shah, A. H. \& Khalil, H. S. Oil pulling and importance of traditional medicine in oral health maintenance. Int. J. Health Sci. (Qassim), 11(4):6570, 2017.

Peedikayil, F. C.; Sreenivasan, P. \& Narayanan, A. Effect of coconut oil in plaque related gingivitis - A preliminary report. Niger Med. J., 56(2):143-7, 2015.

Peedikayil, F. C.; Remy, V.; John, S.; Chandru, T. P.; Sreenivasan, P. \& Bijapur, G. A. Comparison of antibacterial efficacy of coconut oil and chlorhexidine on Streptococcus mutans: An in vivo study. J. Int. Soc. Prev. Community Dent., 6(5):447-52, 2016.

Restrepo, M.; Zabala, L. \& Guiot, L. Aceite de Coco: Características nutricionales y posibles aportes a la salud humana. (Tesis de Pregrado inédita). Universidad Lasallista, 2020.

Romero-González, M. A. Azúcar y caries dental. Odontol. Pediatr., 18(1):4-11, 2020.

Rukmini, J. N.; Manasa, S.; Rohini, C.; Sireesha, L. P.; Ritu, S. \& Umashankar, G. K. Antibacterial efficacy of tender coconut water(Cocos nucifera L) on Streptococcus mutans: An in-vitro study. J. Int. Soc. Prev. Community Dent., 7(2):130-4, 2017.

Rupani, R. \& Chavez A. Medicinal plants with traditional use: Ethnobotany in the Indian subcontinent. Clin. Dermatol., 36(3):306-9, 2018.

Seleem, D.; Chen, E.; Benso, B.; Pardi, V. \& Murata, R. M. In vitro evaluation of antifungal activity of monolaurin against Candida albicans biofilms. PeerJ., 4:e2148, 2016.

Sezgin, Y.; Memis Ozgul, B. \& Alptekin, N. O. Efficacy of oil pulling therapy with coconut oil on four-day supragingival plaque growth: A randomized crossover clinical trial. Complement. Ther. Med., 47:102193, 2019.

Silva, V. O.; Pereira, L. J.; Pasetto, S.; da Silva, M. P.; Meyers, J. C. \& Murata, R. M. Effects of Monolaurin on Oral Microbe-Host Transcriptome and Metabolome. Front. Microbiol., 9:2638, 2018.

Singla, N.; Acharya, S.; Martena, S. \& Singla, R. Effect of oil gum massage therapy on common pathogenic oral microorganisms A randomized controlled trial. J. Indian Soc. Periodontol., 18(4):441-6, 2014.
Tartaglia, G. M.; Tadakamadla, S. K.; Connelly, S. T.; Sforza, C.; Martín, C. Adverse events associated with home use of mouthrinses: a systematic review. Adverse events associated with home use of mouthrinses: a systematic review. Ther. Adv. Drug. Saf., 10:2042098619854881, 2019.

Torres, A. Efecto antimicrobiano del aceite de coco sobre cepas de EStreptococcus mutans. Estudio in vitro. (Tesis de Pregrado inédita). Universidad Central del Ecuador, 2017.

Woolley, J.; Gibbons, T.; Patel, K. \& Sacco, R. The effect of oil pulling with coconut oil to improve dental hygiene and oral health: $A$ systematic review. Heliyon, 6(8):e04789, 2020.

Corresponding author:

Grecia Paola Vásquez Vereau

Cirujano Dentista COP: 44830

Universidad Nacional de Trujillo

Monserrate - Trujillo 13008

PERÚ

E-mail: greciavasquezvereau@hotmail.com 